\title{
UNSUR PSIKOLOGI MASLOW DALAM NOVEL TERPILIH
}

\author{
Maslow's Psychological Elements in Selected Novels
}

\author{
Nurhamizah Hashim \\ aaee@um.edu.my \\ Eizah Mat Hussain \\ eizah@um.edu.my \\ Nur Yuhanis Mohd Nasir \\ yuhanis83@um.edu.my
}

Universiti Malaya

\begin{abstract}
ABSTRAK
Bagi golongan remaja terutamanya, aspek keperluan keselamatan ini amat dititikberatkan dalam kehidupan seharian mereka. Namun, terdapat ibu bapa yang masih tidak memahami keperluan yang diperlukan oleh remaja dan anakanak mereka. Golongan remaja ini inginkan ibu bapa atau penjaga yang sefahaman dan sentiasa memberikan sokongan dari semua segi. Kertas kerja ini membincangkan dua novel untuk remaja; Merdekakan Cinta Ratna (2003) karya Sri Rahayu Mohd Yusop dan Beraraklah Awan Pilu (2006) karya Abd. Latip Talib dalam aspek keperluan keselamatan. Aspek keperluan keselamatan merupakan salah satu peringkat yang terdapat dalam Teori Hierarki Keperluan Manusia (Abraham H. Maslow). Aspek keperluan keselamatan terbahagi kepada keselamatan fizikal, keselamatan emosi dan kestabilan ekonomi. Tujuan kajian ini untuk mengenal pasti dan menganalisis aspek keperluan keselamatan yang ditonjolkan oleh pengarang dalam karya mereka. Hasil kajian mendapati watak-watak dalam novel cuba memenuhi, mengelak dan menghindari ancaman dari keperluan keselamatan fizikal, emosi dan kestabilan ekonomi dengan cara menghadapi masalah yang dilalui.
\end{abstract}

Kata Kunci: hierarki keperluan manusia; keperluan keselamatan; teks; novel; remaja

\begin{abstract}
Safety needs especially for adolescents or teenagers is one of the essential needs in their routine lifestyle. However, some parents do not understand their teenagers' needs. In general, teenagers wish for their parents' or guardians to understand them and to give full support in every aspect of their lives. This paper discusses two novels for adolescents titled "Merdekakan Cinta Ratna" (2003) by Sri Rahayu Mohd Yusop and "Beraraklah Awan Pilu" (2006) by Abd. Latip Talib in the aspect of safety needs. This aspect is according to one of the stages in the hierarchy of human needs by Abraham H. Maslow. Safety needs can be divided into physical safety, emotional safety and economic stability. The purpose of this research is to identify and analyze the safety needs being highlighted by the authors in their respective writings. Through this research, it is found that main characters in the novels try to fulfill, avoid and escape difficulties or troubles from safety needs by facing all the obstacles.
\end{abstract}

Keywords: hierarchy of human needs; safety needs; text; novels; and teenagers

\section{PENGENALAN}

Umumnya, novel remaja merupakan salah satu genre atau cabang yang terdapat di dalam sastera remaja selain puisi, drama, cerpen dan lain-lain. Novel remaja memainkan peranan yang penting dalam mendidik serta membentuk keperibadian golongan remaja ke arah yang bersifat positif. Tema yang diketengahkan dalam novel remaja mencakupi pelbagai tema yang jauh berbeza daripada tema untuk novel umum seperti tentang pengalaman kehidupan, permasalahan kesan interaksi dengan alam sekeliling, cerita berkaitan 
jenayah, hantu, selain tema kekeluargaan, konflik di sekolah, dalam lingkungan kawan-kawan dan persahabatan. Tidak terkecuali juga karya-karya yang menganjurkan muhibah dan perpaduan di samping yang bersifat nasionalisme.

Novel remaja banyak menonjolkan perkara-perkara yang positif, perkara kebaikan serta perkara yang memberikan pengajaran dan teladan, secara tidak langsung boleh menjadi medium untuk mendorong serta meningkatkan motivasi kepada golongan pembaca khususnya golongan remaja dalam mengejar dan mencapai matlamat dalam kehidupan mereka. Setiap manusia mempunyai matlamat dalam meneruskan kehidupan. Motivasi serta emosi memainkan peranan yang amat penting dalam pembentukan sesuatu tingkah laku, imej dan personaliti peribadi seseorang remaja. S.Othman Kelantan (1987:16) menjelaskan bahawa novel merupakan rakaman kehidupan realiti manusia yang dilakarkan dalam bahasa kreatif, yang mencakupi pelbagai masalah kehidupan dengan liku-liku yang dapat dilihat secara zahir atau secara batin. Hal ini turut merangkumi masalah kepercayaan dan iman kepada tuhan, keraguan dan segala bentuk pemikiran yang telah digarap dengan imaginasi dan fantasi penulis. Watak remaja yang cuba ditonjolkan oleh setiap pengarang dalam novel mereka menggambarkan realiti kehidupan remaja. Menurut Sohaimi Abdul Aziz (1992:91), hal ini disebabkan oleh kehidupan masyarakat dan pengarang yang menjadi bahan mentah dalam penulisan kreatif. Kehidupan masyarakat yang pelbagai bentuk dan ragam menjadi ilham pengarang untuk berkarya.

Antara perkara atau isu yang sering ditonjolkan dalam sesebuah karya salah ialah unsur psikologi. Psikologi merupakan bidang yang bertujuan untuk memahami tingkah laku manusia, menghuraikan atau memperihalkan tingkah laku manusia, membantu dan meramalkan tingkah laku manusia, mengawal tingkah laku manusia dan akhir sekali membentuk serta mempengaruhi tingkah laku manusia (Mohd Salleh Lebar,1994:3-4). Salah satu teori yang memperkatakan tentang psikologi manusia ini ialah Teori Hierarki Keperluan Manusia yang telah diperkenalkan oleh Abraham H. Maslow pada tahun 1943. Menurut Maslow, Teori Hierarki Keperluan Manusia ini digunakan untuk melihat pola keperluan manusia. Setiap individu akan cuba memenuhi tuntutan keperluan mereka. Teori ini terdiri daripada lima peringkat keperluan yang utama, iaitu (i) keperluan fisiologi, (ii) keperluan keselamatan, (iii) keperluan kasih sayang dan keinginan dimiliki, (iv) keperluan penghargaan kendiri, dan (v) keperluan penyempurnaan kendiri. Namun begitu, kertas kerja ini hanya akan melihat keperluan di peringkat yang kedua sahaja, iaitu keperluan keselamatan dalam novel remaja.

Novel remaja yang menjadi pilihan dalam kajian ini ialah novel Merdekakan Cinta Ratna karya Sri Rahayu Mohd Yusop dan novel Beraraklah Awan Pilu karya Abd. Latip Talib. Tujuan kajian ini dilakukan adalah untuk mengenal pasti dan menganalisis bentuk keperluan keselamatan yang diperlukan oleh watak remaja yang terdapat dalam novel yang telah dipilih. Kedua-dua novel ini dipilih kerana watak-watak utama dalam novel mengetengahkan sikap, tingkah laku dan perbuatan remaja yang memerlukan keperluan keselamatan dari pelbagai aspek.

\section{KAJIAN LEPAS}

Terdapat beberapa kajian yang telah dilakukan dengan menggunakan Teori Hierarki Keperluan Manusia terhadap teks sastera. Antaranya kajian yang dilakukan oleh Halis Azhan Mohd Hanafiah (2002) yang bertajuk Novel-Novel Zailiani Taslim: Analisis Kehendak Remaja. Halis Azhan Mohd Hanafiah telah mengkaji tentang watak dan perwatakan serta kehendak remaja, di samping mengapa kehendak itu muncul, tindakan-tindakan yang dilakukan oleh watak remaja untuk mencapai kehendak tersebut dan kesan yang terhasil daripada tindakan yang dilakukan oleh watak. Sebanyak enam buah novel remaja karya penulis prolifik, iaitu Zailani Taslim telah dijadikan sebagai bahan kajian.

Selain itu, terdapat juga kajian dari luar negara yang telah mengaplikasikan Teori Hierarki Keperluan Manusia dalam bidang sastera, misalnya kajian telah dilakukan oleh Mohammad Hanif (2009) dari University of Maulana Malik Ibrahim, Malang, Indonesia dalam tesisnya yang bertajuk "The Main Character's Need in Elizabeth Dunkle's Every Woman Loves Russian Poet (Based on Abraham Maslow's Theory)". Muhammad Hanif telah melakukan kajian terhadap novel Every Women Loves Russian Poet karya Elizabeth Dunkle's. Hanya keperluan watak utama (Katia) dalam novel yang telah dikaji. 


\section{KEPERLUAN KESELAMATAN}

Setiap individu memerlukan keperluan keselamatan tetapi dengan kekuatan yang berbeza. Misalnya ada individu yang kurang mendapat keperluan ini dan menjadikannya lebih gemar menyendiri daripada masyarakat. Namun begitu, ada juga individu yang mempunyai atau mendapat keperluan ini secara berlebihan sehingga menjadikannya seorang manusia yang sangat bergantung dalam banyak perkara pada orang lain yang berada di sekitarnya. Keperluan ini timbul daripada keadaan kanak-kanak yang tidak dapat hidup sendiri atau berdikariyang banyak bergantung pada ibu dan bapa mereka. Hal ini bertujuan bagi mendapatkan keperluan keselamatan supaya mereka merasai sentiasa dilindungi. Contohnya, jika kanak-kanak ditimpa sesuatu penyakit, mereka ini amat memerlukan jagaan daripada ibu dan bapa bagi memastikan keselamatan mereka terjamin (Maslow, 1970, p. 39-41).

Bagi individu dewasa pula, mereka amat memerlukan keadaan persekitaran yang stabil, aman, konsisten dan berasa selamat bukan sahaja meliputi aspek fizikal, malah aspek-aspek lain seperti aspek rohani dan aspek emosi. Keperluan ini lahir dari desakan nurani manusia sendiri yang lazimnya tidak akan selesa kalau hidupnya sering diburu ketakutan, kebimbangan dan rasa tidak menentu (Maslow, 1970:41).

Menurut Maslow (1970:39) bentuk-bentuk keperluan keselamatan yang diingini oleh manusia pada peringkat ini ialah seperti petikan berikut:

“....security, stability, dependency, protection, freedom from fear, from anxiety and chaos, need for structure, order, law, limits: strength in the protector, and so on..."

Berdasarkan petikan tersebut, keperluan keselamatan menurut pandangan Maslow ialah seperti keselamatan fizikal, kestabilan ekonomi, mendapat perlindungan undang-undang, bebas mengeluarkan pendapat, kedamaian, bebas dari rasa bersalah, tidak terjebak dalam ketakutan, kebimbangan dan perasaan tidak menentu dan bebas dari huru-hara. Menurut Maslow lagi, bagi menjalani kehidupan sebagai manusia normal, setiap individu sentiasa ingin memastikan diri mereka berada dalam suasana persekitaran yang stabil, konsisten dan selamat.

Di samping itu juga, aspek keselamatan turut merangkumi keselamatan mental dan keselamatan spiritual. Perasaan bimbang, takut, berasa tertekan dan rasa ketegangan akan mengakibatkan manusia terikat pada kedudukan ini dan akan mengakibatkan individu tersebut kerap mempamerkan sikap-sikap negatif (Maslow, 1970, p. 39-43).

Hal ini turut juga berlaku pada golongan remaja. Remaja amat memerlukan keadaan keselamatan yang menunjukkan suasana yang aman, harmoni serta persekitaran hidup yang terjamin dan selamat. Remaja juga memerlukan perlindungan dan bebas daripada perasaan bimbang, tegang, kekecewaan, kesedihan dan ketakutan.

Apabila keperluan ini tidak dipenuhi, maka remaja akan sentiasa mengalami perasaan tidak selamat dan ketakutan. Selain itu remaja juga sukar bergerak untuk mencapai keperluan pada peringkat seterusnya. Bagaimanapun, Maslow berpendapat bahawa keperluan keselamatan tidak akan mendapat keutamaan selagi keperluan fisiologi masih belum dipuaskan(Maslow, 1970:43).

Aspek keselamatan yang dikemukakan oleh Maslow seperti yang telah dinyatakan di atas sememangnya mempunyai persamaan dengan keselamatan yang dituntut dalam Islam. Islam dan manamana agama di dunia ini amat menggalakkan pengikutnya menjaga diri, menjauhi permusuhan, mementingkan kestabilan ekonomi dan mengelakkan peperangan. Permusuhan sesama sendiri dan peperangan akan merugikan diri sendiri dan masyarakat dalam sesebuah negara. Hal ini dapat dibuktikan berdasarkan beberapa ayat al-Quran yang melarang manusia merosakkan diri sendiri, melakukan kerosakan di atas muka bumi, Allah SWT berfirman:

"Dan di antara manusia ada orang yang ucapannya tentang kehidupan dunia menarik hatimu dan dipersaksikannya kepada Allah (atas kebenaran) isi hatinya padahal ia adalah penentang yang paling keras. Dan apabila ia berpaling (dari kamu) ia berjalan di bumi untuk mengadakan kerosakan padanya dan merosak tanam-tanaman dan binatang ternak dan Allah tidak menyukai kebinasaan”.

(Surah al-Baqarah: Ayat 204-205)

Allah SWT telah melarang dan mengharamkan keganasan yang diistilahkan dalam al-Quran sebagai kebinasaan atau kerosakan. Hal ini kerana keganasan boleh membinasakan atau merosakkan 
pelbagai ciptaan Allah, sama ada di daratan, di udara, di lautan atau di mana sahaja keganasan tersebut terutamanya yang melibatkan nyawa atau mengakibatkan kerosakan harta benda milik kerajaan, milik awam atau milik peribadi.

Berdasarkan kepada peringkat keperluan keselamatan ini, Maslow (1970) berpendapat bahawa aspek keselamatan fizikal, keselamatan emosi, kestabilan ekonomi, mendapat perlindungan undangundang, bebas mengeluarkan pendapat, kedamaian, bebas dari rasa bersalah, tidak terjebak dalam ketakutan, kebimbangan dan perasaan tidak menentu dan bebas dari huru- hara. Dalam kajian ini, terdapat tiga aspek pada peringkat keperluan keselamatan yang akan digunakan dalam analisis, iaitu keselamatan fizikal, keselamatan emosi, dan kestabilan ekonomi.

\section{KESELAMATAN FIZIKAL}

Keselamatan dari aspek fizikal hadir dalam bentuk ancaman, baik secara lisan mahupun bertulis, untuk menyakiti tubuh (fizikal) watak. Usaha mengelak daripada disakiti atau mengalami kesakitan akibat sebarang penyakit menjadi fitrah manusia.

Dalam novel Merdekakan Cinta Ratna karya Sri Rahayu MohdYusop, terdapat satu keperluan keselamatan fizikal yang ditonjolkan oleh watak utamanya, seorang remaja bernama Muhammad. Dalam hal ini, Muhammad ingin bebas dari ancaman ayahnya kerana sering kali berasa tidak selamat apabila ayahnya berada di rumah. Desakan utama Muhammad ingin memenuhi keperluan ini adalah kerana Muhammad dan ibunya sering menjadi mangsa sikap panas baran ayah Muhammad. Malah Muhammad sering dipukul oleh ayahnya tanpa rasa belas kasihan. Buktinya seperti petikan berikut:

Ayah datang dan campak kesemuanya ke dalam parit di hadapan orang-orang yang ada di situ. Aku ayah jinjing naik ke atas motosikal dan apabila sampai di kebun jagung di seberang parit depan rumahku, ayah kenakan aku. Aku terbaring saja di situ, tidak mendengar nafasku, tidak nampak apa-apa, seolah-olah aku dilindungi daripada untuk merasa. Apabila sedar, aku bangkit dan balik ke rumah. Rumah itu umpama telah digeledah keseluruhannya, dan ibu sedang menangis. Aku tahu ibu telah mendapat habuannya.

(Merdekakan Cinta Ratna, 2003, p. 109)

Berdasarkan petikan tersebut digambarkan bagaimana Muhammad dan ibunya telah dipukul oleh ayah Muhammad tanpa balas kasihan. Hal ini dapatlah dirumuskan bahawa kehidupan Muhammad dan ibunya amat terseksa akibat perbuatan dan sikap seorang ayah (kepada Muhammad) dan suami (kepada ibu Muhammad).

Justeru, tindakan yang telah dilakukan oleh Muhammad bagi menyelamatkan dirinya dan ibunya daripada menjadi mangsa ayahnya ialah Muhammad berusaha serta mencari kekuatan untuk berhadapan dan melawan ayahnya. Perkara ini berlaku apabila ibu Muhammad dipukul oleh ayahnya, Muhammad hanya bersembunyi di dalam biliknya sahaja. Hal ini digambarkan dalam petikan berikut:

Aku hanya duduk di dalam bilik, seolah-olah boleh melegakan sakit perit ibu kalau aku tidak melihat apa yang terjadi. Tapi aku dengar segala-galanya. Aku dengar segala-galanya seperti aku berada di dalam terowong, berdengung-dengung. Ibu langsung tidak bersuara. Hanya ayah yang terjerit pekik, menyeranah dengan perkataan-perkataan yang aku tak ingin catatkan atau ingat atau sebut lagi. Buat sekian kali aku dengar hempasan pinggan mangkuk, satu demi satu, juga pukulan-pukulan seperti orang membanting padi. Aku tahu kenapa ibu tidak bersuara. Kerana ibu tidak mahu aku dengar. Kerana dia tahu ini akan merosakkanku.

(Merdekakan Cinta Ratna, 2003, p. 2)

Berdasarkan petikan berikut, Muhammad telah membuat tindakan berani dengan tidak menyembunyikan diri lagi apabila ayahnya memukul ibunya. Hal ini kerana Muhammad telah bertekad untuk tidak meninggalkan ibunya sewaktu dipukul ayahnya. Tindakan Muhammad ini menunjukkan wujud keperluan keselamatan dari aspek fizikal apabila mendapat ancaman daripada ayahnya. Muhammad telah cuba untuk menemani ibunya ketika dipukul ayahnya tanpa menyembunyikan diri seperti sebelumnya. 
Muhammad terus memeluk ibunya dari belakang.

"Saya dah sedia mak. Saya dah sedia"

Ibunya terkejut.

"Sedia untuk apa Muhammad?"

Ibunya meleraikan rangkulan Muhammad. Muka anak tunggalnya dipegang dengan kedua-dua belah tangan.

"Saya takkan tinggalkan mak. Muhammad akan bersama mak selama-lamanya."

"Kau tak pernah tinggalkan mak. Kau ada di sini."

"Tapi saya lari, saya sembunyi."

"Tak mengapa Muhammad. Ini semua salah mak."

"Saya akan ada di sisi mak walau apa pun jadi."

(Merdekakan Cinta Ratna, 2003, p. 88-89)

Selain itu, Muhammad telah membuat tindakan berani dengan menegur dan membalas perbuatan ayahnya yang pulang dalam keadaan kemarahan. Hal ini digambarkan dalam petikan berikut:

Ayahnya telah menolak motosikalnya sehingga jentera kesayangan itu terbaring di atas tanah.

"Awak turun Waini!" ayah memerintah. Berderai air mata ibu. Ibu tahu apa yang bakal berlaku. Ibu akur sebab itulah caranya untuk sekian lama.

Muhammad menerpa ke pintu dan melompat ke tanah.

"Ayah, itu motosikal saya! Kenapa ayah buat macam ni?"

Muhammad betul-betul geram. Dia masih ingat betapa jerih-perih ibunya membelikan motosikal itu.

Harapkan ayah jauh sekali.

"Emaknya bodoh, anaknya pun bodoh!"

(Merdekakan Cinta Ratna, 2003, p. 113)

Ayahnya ayun parang, kena pada lampu belakang motosikal. Lampu belakang motosikal itu terkulai.

Sekali lagi ayun, ia tercampak jauh ke dalam semak.

"Ayah! Ini motosikal saya!" Muhammad merayu. Ayahnya ke hadapan dan lampu hadapan pula menjadi sasaran. Berderai.

“Kau tak pandai jaga motosikal, biar aku rosakkan sekali!” jerkahnya.

Muhammad begitu terdesak. Dia meluru lalu di paut tangan ayahnya dengan kuat. Ayahnya terhenti di situ.

(Merdekakan Cinta Ratna, 2003, p. 114)

"Saya hadapi, saya tak lari lagi, tak lari lagi..." Muhammad tercungap-cungap. Menahan perit dengan ilusi dia telah berjaya.

(Merdekakan Cinta Ratna, 2003, p. 125)

Berdasarkan petikan tersebut, jelas menunjukkan bahawa aspek keperluan keselamatan Muhammad telah terancam dengan tindakan ayahnya yang telah menolak motosikalnya. Muhammad telah berhadapan dengan ayahnya apabila ayahnya cuba merosakkan motosikalnya dengan menggunakan parang. Tindakan yang dilakukan oleh Muhammad merupakan satu bentuk cara mengelak daripada disakiti akibat perbuatan ayahnya menolak motosikalnya.

Keperluan keselamatan telah dipenuhi oleh Muhammad kesan daripada tindakan Muhammad dengan tidak hanya melihat atau menyembunyikan dirinya ketika ibunya dipukul. Muhammad telah bertindak apabila mendapat ancaman dalam bentuk fizikal dengan perbuatan ayahnya yang sering memukul ibunya. Hal ini terbukti apabila Muhammad telah meminta pertolongan Ustaz Ilyas dan En. Sethemberan ketika ayahnya memukul ibunya.

Dengan tindakan yang dilakukan oleh Muhammad, Muhammad dan ibunya telah bebas dari ayahnya yang panas baran serta ibu Muhammad pula bebas dari menjadi mangsa suaminya yang merupakan seorang kaki pukul. Peristiwa ini merupakan tindakan keperluan keselamatan dari aspek fizikal yang diperlukan oleh Muhammad. Muhammad telah mengambil tindakan yang sewajarnya untuk mengatasi masalah yang dihadapi dengan berhadapan masalah tersebut. Peristiwa ini berakhir dengan ayah 
Muhammad, iaitu Pak Hamdan telah ditahan oleh pihak polis. Setelah ayahnya ditahan oleh pihak polis, Muhammad merasakan dirinya tidak lagi mempunyai ancaman dalam kehidupan.

Dalam novel Beraraklah Awan Pilu pula, keperluan keselamatan ditonjolkan melalui watak Syafiq apabila beliau mahu ayahnya bebas dari ancaman musuh dalam dunia perniagaan. Keperluan keselamatan ini lebih kepada berbentuk keselamatan fizikal. Justeru itu, disebabkan desakan utama bagi memenuhi keperluan ini kerana ayah Syafiq mempunyai ramai musuh dalam bidang perniagaan. Hal ini digambarkan dalam peristiwa yang berlaku apabila ayahnya telah ditikam oleh dua orang perompak ketika ayahnya baru keluar dari bank. Dalam konteks ini, Syafiq berada dalam ketakutan akibat peristiwa tersebut. Perkara ini digambarkan dalam petikan berikut:

Sebaik sahaja keluar dari bank, Dato'Mansor terus menuju ke arahnya. Tiba-tiba muncul dua orang pemuda lalu menyerbu dan cuba meragut beg yang dipegang olehnya. Berlakulah pergelutan kerana Dato' Mansor enggan menyerahkan beg bimbitnya. Hampir sahaja Syafiq terlompat dari kereta. Dia menerpa ke arah perompak itu. Seorang daripadanya berjaya ditewaskan. Tetapi seorang lagi sempat menikam perut Dato'Mansor dan merampas beg tersebut serta berjaya melarikan diri.

(Beraraklah Awan Pilu,2006, p. 166-167)

Berdasarkan petikan tersebut, ancaman keperluan keselamatan telah dialami oleh Syafiq apabila berlakunya rompakan ke atas dirinya dan ayahnya. Syafiq telah mengambil tindakan dengan berlawan dengan perompak untuk mengelak ancaman dari disakiti. Namun, usaha yang dilakukan oleh Syafiq tidak berjaya kerana ayahnya telah ditikam oleh perompak tersebut. Namun, dalam konteks ini, keperluan keselamatan amat diperlukan bukanlah ke atas diri Syafiq, sebaliknya keperluan keselamatan untuk ayahnya.

Dalam kedua-dua buah novel menggambarkan watak-watak yang telah mendapat ancaman dari aspek keperluan fizikal. Ancaman tersebut telah menyebabkan watak-watak mengambil tindakan untuk mengelakkan diri dari disakiti. Tindakan-tindakan yang dilakukan dengan memberanikan diri menghadapi masalah yang dihadapi dan berlawan atau bergaduh untuk mempertahankan diri. Oleh itu, jelaslah keduadua novel menonjolkan watak yang bertindak untuk memenuhi keperluan keselamatan apabila mendapat ancaman disakiti.

\section{KESELAMATAN EMOSI}

Keselamatan dari aspek emosi boleh ditakrifkan sebagai terhindar dan terpelihara dari perkara-perkara yang boleh mendatangkan keburukan kepada perasaan seseorang individu seperti emosi sedih, dukacita, sengsara, bimbang, takut, rasa tidak selamat, rasa bersalah dan sebagainya. Sebagai manusia normal, emosi-emosi yang telah disebut seperti di atas sememangnya sering dialami oleh manusia. Namun begitu, seseorang individu boleh mengelak dan menghindarkan diri mereka dari terjebak ke dalam emosi berikut dengan melakukan pelbagai cara (Abraham H. Maslow, 1979).

Keselamatan emosi yang diperlukan oleh watak Muhammad (novel Merdekakan Cinta Ratna) ialah bebas dari perasaan sedih, kecewa dan marah. Perasaan ini timbul apabila Muhammad sering dipukul oleh ayahnya yang mempunyai sikap panas baran. Hal ini telah menimbulkan perasaan marah dan kecewa dengan tindakan ayahnya yang sepatutnya sebagai seorang ayah perlu melindungi anaknya bukan memukul anaknya. Di samping itu, perasaan kecewa, sedih dan marah turut dialami oleh Muhammad apabila mendengar ibunya menjadi mangsa maki hamun dan dipukul oleh ayahnya. Perkara ini dapat digambarkan dalam petikan berikut:

Tapi dia ayahku, sepatutnya dia melindungi aku daripada segala kedahsyatan di dalam dunia ini. tapi idealismeku meleset. Aku akhirnya kecewa dengan diriku sendiri.

(Merdekakan Cinta Ratna, 2003, p. 110)

Desakan utama untuk memenuhi keperluan emosi ini adalah kerana Muhammad sudah tidak tahan lagi menanggung segala derita yang dilaluinya sepanjang usianya 19 tahun. Bagi Muhammad, sifat seorang ayah haruslah menyayangi malah melindungi anak isteri dan bertanggungjawab terhadap keluarganya. Namun begitu, ayah Muhammad tidak pernah menunjukkan sikap melindungi dan 
bertanggungjawab serta perasaan kasih dan sayangnya terhadap Muhammad seperti mana yang sepatutnya dilakukan oleh seorang ayah. Perkara ini telah menyebabkan Muhammad berasa amat sedih dengan nasib yang menimpa beliau dan ibunya. Ancaman keperluan emosi berlaku apabila ayah Muhammad tidak menjalankan tugas seorang ayah yang bertanggungjawab terhadap memberi makan, minum, pakaian dan rumah kediaman semata-mata kepada ahli keluarga tetapi tugas seorang bapa termasuk melindungi dan memelihara ahli keluarga dari aspek keimanan dan sebagainya supaya mereka tidak hanyut dalam arus kehidupan yang bertentangan dengan fitrah kejadian manusia

Oleh itu, tindakan yang telah dilakukan oleh Muhammad bagi memenuhi keperluan emosi ini dengan menawarkan diri untuk menulis skrip pementasan drama yang akan berlangsung di sekolahnya. Dalam penulisan skrip tersebut Muhammad telah menumpahkan segala perasaan dan kesakitannya terhadap ayahnya selama ini. Keseluruhan skrip drama itu menggambarkan tentang ayahnya yang tidak bertanggungjawab, panas baran, terlalu mengikut perasaan, khianat terhadap keluarga dan sebagainya. Tindakan Muhammad dengan meluahkan dan menumpahkan segala kesakitannya dalam skrip drama ini telah menyebabkan ada dalam kalangan kawan-kawan sekelasnya dan cikgu yang menyedari akan hal tersebut.

“Aku rasa ada sesuatu dalam cerita ni yang sama dengan diri Muhammad," Chai Fen menukar tajuk. (Merdekakan Cinta Ratna, 2003, p. 74)

Setelah mengetahui rahsia hitam Muhammad, Cikgu Soraya jadi insaf terhadap keseluruhan skrip drama itu. Seolah-olah Muhammad menumpahkan segala kesakitannya ke dalam sembilan babaknya.

(Merdekakan Cinta Ratna, 2003, p. 136)

Berdasarkan petikan berikut, menunjukkan Muhammad melepaskan ancaman keperluan emosi yang dialami dengan meluahkan dalam bentuk skrip. Kesan daripada ancaman keperluan emosi yang telah dialami oleh Muhammad, iaitu perasan terluka, kecewa, marah dan sedihnya terhadap ayahnya semakin berkurangan kerana telah diluahkan perasan itu dalam bentuk skrip. Malah Muhammad turut diterima menjadi sebahagian daripada kumpulan sutradara drama merdeka. Perkara ini menunjukkan keperluan keselamatan dari aspek emosi yang diperlukan oleh Muhammad dan tindakan yang telah diambil oleh beliau bagi memenuhi keperluan ini dengan menumpahkan segala perasaan kesakitannya dalam karya skrip dramanya.

Selain itu, peringkat keselamatan emosi ini turut ditemui dalam novel Beraraklah Awan Pilu. Melalui watak Syafiq peringkat keselamatan emosi dikesan dengan tindakannya mahu bebas dari perasaan sedih yang melanda dirinya sejak beliau masih kecil lagi. Perasaan ini membelenggu diri Syafiq kerana kawan-kawannya dan penduduk kampung sering mengatakan bahawa beliau anak haram dan anak tiada berbapa merupakan ancaman keperluan emosi yang dihadapinya. Hal ini digambarkan dalam petikan berikut:

Sejak kecil, itulah kata-kata yang selalu dilemparkan kepadanya. Paling menyedihkan apabila menyambut hari raya. Kawan-kawan yang sebaya dengannya berjalan ke masjid dengan ayah masing-masing, tetapi dia bersendirian.

(Beraraklah Awan Pilu, 2006, p. 11)

Petikan tersebut menggambarkan ancaman keperluan emosi yang dihadapi oleh Syafiq apabila melihat kawan-kawannya berjalan dengan ayah masing-masing ke masjid. Ancaman keperluan emosi yang dihadapi oleh Syafiq tidak dapat ditahan olehnya lagi. Justeru itu, tindakan yang dilakukan oleh Syafiq dengan bertanya kepada ibunya tentang ayah kandungnya. Hal ini merupakan tindakan yang dilakukan oleh Syafiq untuk mengelak atau mengatasi ancaman keperluan emosi yang dialami. Perkara ini digambarkan dlam petikan berikut:

“Mak betulkah Syafiq tak ada ayah?” Begitu dia bertanya sambil menggoncang tangan ibunya. Ibunya tidak menjawab. Hanya air mata yang tumpah. Tetapi itu dulu. Semasa dia masih anak-anak. Apabila dia sudah besar dan berjaya melanjutkan pelajaran ke universiti, ibunya tidak dapat menyimpan rahsia lagi.

"Syafiq bukan anak haram. Mak dan ayah Syafiq menikah secara sah." 
Justeru itu, Syafiq telah pergi ke Brunei bagi mencari ayah kandungnya yang hilang sejak beliau masih dalam kandungan ibunya bagi mengatasi ancaman keperluan emosi yang dihadapinya. Kesan daripada tindakan Syafiq pergi mencari ayah kandungnya di Brunei ialah beliau akhirnya telah bertemu dengan ayah kandungnya serta perasaan sedih yang ditanggung selama ini telah hilang serta-merta malah digantikan dengan perasaan gembira dan bahagia. Hal ini menunjukkan keperluan keselamatan dari aspek emosi yang diperlukan oleh Syafiq telah dipenuhi. Beliau akhirnya telah berjaya memenuhi keperluan ini apabila mengambil tindakan yang sepatutnya untuk mendapat maklumat mengenai bapa kandungnya daripada ibunya.

Berdasarkan kedua-dua novel, watak-watak utama telah mengalami ancaman keperluan emosi dalam kehidupan. Ancaman dari keperluan emosi telah mendatangkan perasaan sedih, kecewa, dan marah dalam diri watak-watak. Bagi mengatasi ancaman keperluan emosi ini, watak-watak cuba mengelak atau mengatasi dengan pelbagai cara terutamanya menyelesaikan masalah yang dihadapi.

\section{KESTABILAN EKONOMI}

Kestabilan ekonomi yang dikemukakan oleh Maslow (1970, p. 39) mempunyai kaitan dengan pendapatan atau kekukuhan sistem ekonomi sama ada seseorang individu atau keluarga. Namun begitu, Maslow tidak menjelaskan secara terperinci tentang aspek kestabilan ekonomi ini. Bagi manusia normal, aspek kestabilan ekonomi ini amat penting bagi menjalani kelangsungan hidup. Golongan dewasa memerlukan pekerjaan dan pendapatan yang tetap dan stabil setiap bulan untuk menyara keluarga, terutamanya bagi yang telah mendirikan rumah tangga.

Keselamatan dari aspek kestabilan ekonomi sememangnya merupakan perkara yang penting bagi menjalani kehidupan seharian. Hal ini turut disokong oleh Syed Muhammad Naquid Al Attas (1995:43) dengan mengatakan bahawa asas-asas penting dalam kehidupan manusia ialah mempunyai pendapatan yang stabil, ekonomi yang kukuh, tempat penginapan yang selesa, pendidikan dan sokongan keluarga.

Bagi golongan remaja pula, kebiasaannya mereka tidak terlibat secara mendalam dari aspek kestabilan ekonomi ini. Hal ini kerana mereka masih bersekolah dan mereka masih di bawah tanggungjawab atau tanggungan kedua-dua ibu bapa mereka. Namun begitu, terdapat segelintir golongan remaja yang mengalami masalah dari aspek kestabilan ekonomi ini jika mereka berasal dari keluarga yang susah, miskin atau ibu bapa tidak mempunyai pendapatan yang tetap dan stabil. Perkara sebegini akan menyebabkan remaja berkenaan mencari jalan sendiri untuk memenuhi keperluan mereka dari aspek kestabilan ekonomi ini.

Keperluan keselamatan dari aspek kestabilan ekonomi ditemui melalui watak Muhammad dalam novel Merdekakan Cinta Ratna. Hal ini kerana, Muhammad perlu membantu ibunya mengukuhkan ekonomi keluarga mereka. Desakan utama Muhammad perlu memenuhi keperluan ini kerana ekonomi keluarga Muhammad tidak menentu dan tidak kukuh disebabkan ayah Muhammad merupakan seorang yang tidak bertanggungjawab malah tidak mempunyai pekerjaan dan pendapatan yang tetap.

Oleh hal yang demikian, bagi memenuhi keperluan ini, Muhammad telah membantu ibunya menjual nasi lemak serta melakukan beberapa kerja kampung seperti menebas pisang di sekeliling rumahnya. Kesan daripada tindakan yang telah dilakukan oleh Muhammad ini, akhirnya ekonomi keluarga Muhammad berada di tahap sederhana. Malah mereka (Muhammad dan ibunya) mampu meneruskan kehidupan seharian hasil dari titik peluh sendiri tanpa mengharapkan bantuan dari bapa Muhammad. Perkara ini menunjukkan keperluan dari aspek kestabilan ekonomi yang diperlukan oleh Muhammad dalam novel Merdekakan Cinta Ratna telah dipenuhi dengan tindakan Muhammad membantu ibunya menjual nasi lemak. Justeru itu, kesan daripada tindakan Muhammad membantu ibunya telah menstabilkan ekonomi kehidupan mereka.

Dalam novel Beraraklah Awan Pilu ini, kestabilan ekonomi ditemui dalam watak Syafiq yang memerlukan pendapatan dan kedudukan kewangan yang kukuh sepanjang beliau berada di Brunei. Syafiq telah pergi ke Brunei bagi menunaikan wasiat ibunya, iaitu mencari ayah kandungnya yang telah terpisah. Namun begitu, sepanjang berada di Brunei, Syafiq mengalami masalah kewangan. Duit yang dibawa oleh Syafiq semakin berkurangan dari semasa ke semasa. Hal ini berkemungkinan disebabkan oleh mata wang 
Brunei yang lebih tinggi berbanding mata wang Malaysia. Oleh yang demikian, bagi memenuhi keperluan di peringkat ini, maka Syafiq telah menerima tawaran bekerja sebagai pemandu keluarga Dato' Mansor.

"Saya ni memang memerlukan seorang pemandu. Eloklah Syafiq datang. Awak juga ada lesen memandu dan boleh membaiki kereta. Kalau Syafiq sanggup, bolehlah bekerja dengan saya. Gaji boleh kita rundingkan kemudian. Tempat tinggal disediakan.

“Terima kasih, Dato'. Saya setuju menerima tawaran ini. Berapa gajinya terserah kepada budi bicara Dato'...

(Beraraklah Awan Pilu, 2006, p. 68)

Keperluan ekonomi telah dipenuhi oleh Syafiq dengan menerima pelawaan Dato' Mansor bekerja dengannya. Dengan itu, akhirnya Syafiq telah berjaya mempunyai gajinya sendiri untuk menampung keperluan ekonominya. Dalam hal ini, keperluan dari aspek kestabilan ekonomi yang diperlukan oleh Syafiq dan tindakan yang telah dilakukan oleh beliau bagi memenuhi keperluan ini dengan bekerja sebagai pemandu keluarga Dato' Mansor. Oleh itu, keperluan kestabilan ekonomi dapat di atasi oleh watak Syafiq dengan tindakan mencari peluang pekerjaan.

Analisis keperluan ekonomi telah dipenuhi oleh watak dalam kedua-dua buah novel. Bagi memenuhi keperluan ekonomi watak-watak telah bekerja bagi mendapatkan wang untuk menampung keperluan seharian. Watak-watak telah berjaya memenuhi keperluan ekonomi dalam kehidupan mereka.

\section{KESIMPULAN}

Analisis menunjukkan bahawa kedua-dua watak, iaitu Muhammad (Merdekakan Cinta Ratna), dan Syafiq (Beraraklah Awan Pilu) mempunyai kekurangan di peringkat keperluan keselamatan, dari aspek fizikal, emosi dan kestabilan ekonomi yang terdapat dalam Teori Hierarki Keperluan Manusia oleh Abraham H. Maslow. Namun, keperluan keselamatan mereka berbeza-beza mengikut kekurangan masing-masing. Apabila wujud sesuatu kekurangan dalam diri seseorang maka individu tersebut akan mencari jalan atau terdorong untuk memenuhi kekurangan itu. Hasil kajian yang dilakukan, mendapati bahawa watak-watak dalam novel cuba memenuhi, mengelak dan menghindari ancaman dari keperluan keselamatan tersebut.

Kekurangan keperluan keselamatan yang dialami oleh watak-watak dalam novel telah memberikan desakan dan tekanan untuk memenuhi keperluan tersebut. Watak-watak telah mengambil tindakan dalam bentuk tingkah laku yang sesuai dan memberikan kesan daripada tindakan tersebut dapat memenuhi keperluan yang diperlukan. Justeru itu, watak-watak yang digambarkan oleh penulis dalam novel telah memenuhi keperluan keselamatan yang diperlukan mengikut pandangan Maslow.

\section{RUJUKAN}

A. Zainuddin \& Muhammad Jamhari. (1999). Al-Islam 2: muamalah dan akhlak. Bandung: CV. Pustaka Setia Abd.Latip Talib. (2006). Beraraklah awan pilu. Cheras: Utusan Publication \&Distributors Sdn.Bhd.

Abdul Ahmad. (1992). Kajian motif cerpen-cerpen Dewan Siswa 1983-1989. Kuala Lumpur: Dewan Bahasa dan Pustaka.

Ahmad D. Marimba. (1974). Pengantar filsafat pendidikan Islam. Bandung: Penerbit PT Alma Arif.

AinonMohd. (2003). Panduan menggunakan teori motivasi di tempat kerja. Bentong: PTS Publications \& Distributors Sdn.Bhd.

AinonMohd. (2005). Kejayaan dalam diri. Bentong: PTS Publications \& Distributors Sdn.Bhd.

Akmal Hj. Mhd. Zain. (2006). Halal dan haram dalam hehidupan. Kuala Lumpur: Al-Hidayah Publishers

Amina Noor. (2008). Bimbingan mengenal diri untuk remaja. Kuala Lumpur: Utusan Publications \& Distributors Sdn. Bhd.

Aries, P. (1962). Centuries of childhood: a social history of the family. New York: Random House,Inc.

Atan Long. (1976). Psikologi pendidikan. Kuala Lumpur: Dewan Bahasa dan Pustaka.

AziziYahaya\&JaafarSidek Latif. (2005). Membentuk identiti remaja. Bentong: PTS Publication\& Distributor. Sdn.Bhd.

Azlina Abu Bakar@Mohd. (2002). Psikologi personaliti individu. Shah Alam: Karisma Publication Sdn.Bhd. 
Boeree, G. C. (2008). Personality theories melacak keperibadian anda bersama psikolog dunia. Jogjakarta: Penerbit Prismasophie.

Brook, J. A. T, Judith S. \& Brook, D. W. (1978). The psychology of adolescent. New York: Macmillan.

Crain,W. C. (1943). Theories of development concepts and applications. New Jersey: Prentice-Hall. Inc.

DiCaprio, N.S. (1974). Personality theories: guides to living. London: W.B.Saunders Company.

Dorothy, R. (1972). The psychology of adolescene (edisi ke-2). New York: Appleton Century Crofts.

Ee Ah Meng. (1993). Psikologi perkembangan aplikasi dalam bilik darjah (Edisi kedua). Kuala Lumpur: Penerbit Fajar Bakti Sdn. Bhd.

Ensiklopedia sejarah dan kebudayaan Melayu. Jilid IV:R-Z. (1999). Kuala Lumpur: Dewan Bahasa dan Pustaka.

Erikson, E.H. (1965).Childhood and society. England: Penguin Books, Middlesex.

Fuad Abdul Aziz Asy-Syalhub. (2012). Adab dalam Islam. (SuhailaLukman, Terj.). Selangor: Al-Hidayah Publication.

Goble, F. G. (1987). Mazhab ketiga psikologi humanistik Abraham Maslow. Yogyakarta: Penerbit Kanisius.

Goleman D. (1995). Emotional intelligence. New York: Bantam Books.

Griffin, E. (1991). A first look at communication theory. New York: McGraw-Hill.

Hadijah Rahmat. (2006). Peranan dan perkembangan sastera kanak-kanak. Kuala Lumpur: Dewan Bahasa dan Pustaka.

Mahmood Nazar Mohamed. (2005). Pengantar psikologi satu pengenalan asas kepada jiwa dan tingkah laku manusia. Kuala Lumpur: Dewan Bahasa dan Pustaka.

Maslow, A.H. (1970). Motivation and personality, $2^{\text {nd }}$ Edition. New York: Harper and Row Publishers.

MohdSalleh Lebar. (1994). Asas psikologi perkembangan. Kuala Lumpur: Utusan Publication \& Distributors Sdn.Bhd.

S.Othman Kelantan. (1987). Kecenderungan baru dalam novel Melayu: satu kajian struktur. Kuala Lumpur: Dewan Bahasa dan Pustaka.

Sohaimi Abdul Aziz. (1992). Mobiliti sosial perspektif Barat dan Islam dalam novel terpilih Shahnon Ahmad. Kuala Lumpur: Dewan Bahasa dan Pustaka.

Sri RahayuMohd Yusop. (2003). Merdekakan cinta ratna. Cheras: Utusan Publication \& Distributors Sdn.Bhd. Syed Muhammad Naquid Al-Attas. (1995). Prolegomena to the metaphysics of Islam. Kuala Lumpur: ISTAC. 